\title{
EFFECT OF SELENIUM ON THE IMMUNE RESPONSE OF SHEEP VACCINATED \\ WITH PPR VACCINE
}

(With 3 Tables)

\section{By}

I. ISMAIL; A.H. HUSSEIN and A.M. DAOUD (Received at 19/11/2000)

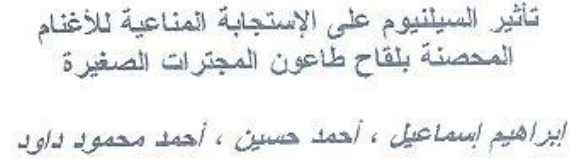

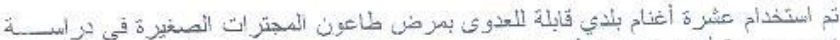

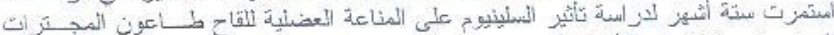

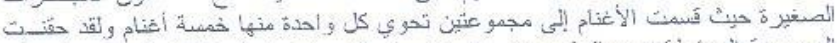

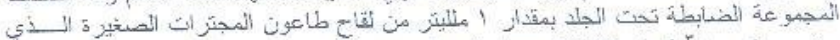

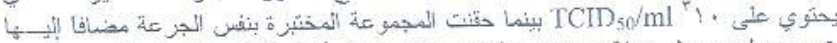

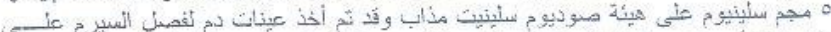

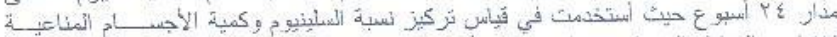

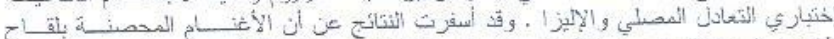

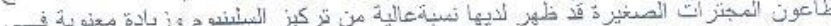

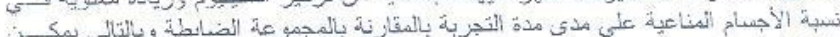

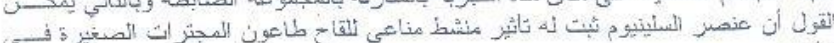

\section{SUMMARY}

Ten Balady sheep susceptible to PPR [Peste des petite ruminant] virus were used in a six-month trial to study the effect of selenium on the humoral immune response of PPR vaccine. They were divided into two groups each of five sheep, control group vaccinated subcutaneously with $1 \mathrm{ml}$ PPR vaccine containing $10^{3} \mathrm{TCID}_{50} / \mathrm{ml}$, test group vaccinated with $1 \mathrm{ml}$ PPR vaccine added to it $5 \mathrm{mg}$ selenium (as sodium selenite dissolved in the diluent). Blood samples were drown weekly for four 
weeks then every two wecks up to 24 weeks post vaccination and assayed for serum selenium concentration, and antibody titres using serum neutralization test and ELISA technique. Compared with those sheep receiving the PPR vaccine alone (control group), sheep received selenium had higher serum selenium concentration and a significant increase in antibody titre during the whole experimental period. Selenium was proved to be immunopotentiating to PPR vaccine in sheep.

Key words: Selenium, sheep, PPR vaccine, immune response

\section{INTRODUCTION}

Several reports have demonstrated the positive effects of selenium on both the cellular and humoral immune responses of laboratory and farm animals. Spallholz et al. (1973) showed that dietary supplementation with non-toxic levels of selenium led to enhanced $\lg G$ and $\operatorname{IgM}$ antibody titre in mice, similarly. Berenstein (1978) reported that rabbits given selenium and vitamin $\mathrm{E}$ before or during immunization with typhoid vaccine had increascd antibody titre, also Bassiouni ct al. (1990) found that the immune response of chickens vaccinated with living Newcastle diseasc vaccine was significantly improved by sclenium supplemented in a diet 14 days before vaccination, while Peplowski et al. (1980) reported that selenium supplementation enhanced the immune response of pigs injected with shecp red cells. Subsequently, it was demonstrated that selenium raised the potency of swine fever vaccine ( $\mathrm{Li}$ and Wang, 1995), but the humoral immune response of horses to tetanus toxoid and equine influenza $A$ virus was increased in selenium and vitamin E supplementation horses (Baalsrud and Overnes, 1986). Selenium injection had improved immunocompetence in cattle as evidenced by the large enhancement of serum $\lg G$ titre in response to Pasteurella haemolyica vaccination (Droke and Loerch, 1989), to IBR (Reffet et al., 1988 a) and to foot and mouth disease vaccine (Ismail, 1999). Selenium supplementation was important to sheep during pregnancy and lactation as it was essential for growth, fertility, thyroid hornone metabolism and immune function (Kolb ct al., 1997 and Wichtel, 1998), selenium supplemented sheep had increased immune response against different pathogen such as tetanus toxoid, parainfluenza-3 virus and Corynebacterium pseudotuberculosis 
(Larsen et al., 1988 and Reffet et al., 1988 b), brucella abortus (Jelinek et al., 1988).

This study was performed in order to ascertain if injectable selenium would enhance the primary immune response of sheep vaccinated with PPR vaccine; PPR is a common cause of an acute. highly contagious disease of goats and sheep which possess a serious threat to the development of small ruminants production in several countries including Egypt (laylor, 1984).

\section{MATERIAL and METHODS}

Animals:

Ten Balady shcep 8-10 month old were placed in hygienic housc and divided into two groups (each of 5 sheep). They were screened for PPR antibodies by serum neutralization test and proved to be free from antibodies. The animals were free from any stress factors.

Sodium selenite $\left(\mathrm{Na}_{2} \mathrm{ScO}_{3}\right)$ :

Obtained from Sigma Co., USA.

Vaccine:

Lyophilized PPR vaccine (an attenuated strain of PPR Egypt 87 adopted on vero cells for 25 passages each dose contained $10^{3} \mathrm{TCID}_{50}$. obtained from VSVRI, Abbassia, Cairo. Control group (5 sheep) were inoculated with $1 \mathrm{ml}$ PPR vaccine $\mathrm{S} / \mathrm{C}$, while test group were inoculated with $1 \mathrm{ml} P$ PR vaccine $\mathrm{S} / \mathrm{C}$ containing $5 \mathrm{mg}$ as sodium selenite dissolved in the diluent.

Blood samples:

Five $\mathrm{ml}$ blood were collected into a sterile MacCartney bottle for separation of serum used for sclenium estimation and SNT and ELISA tests.

Methods:

Serum selenium was estimated using atomic absorption spectrophotometer (Perkin Elmer, USA) with lamb for selenium as done by Little et al. (1979).

Humoral immunity:

Serum neutralization test as described by Rossiter and Jessette (1982) in microtitre plates where two fold serial dilution of the preinactivated tested serum wore done by using Hank's balanced salt solution, serum-virus mixture were incubated at $37^{\circ} \mathrm{C}$ for 1 hour then assayed on vero cells for 9 days incubation. The neutralizing antibody titers werc expressed as the reciprocal of the final dilution of serum in the serum-virus mixture which neutralize an estimated 100 TCID $_{50}$ of 
virus at the $50 \%$ end point estimated according to method of Reed and Mucnch (1938).

\section{ELISA test:}

A modified method after Anderson and McKay (1994) was used to evaluate antibody titre in Nunc Maxisorb. 96 well microtitre plates. Where $50 \quad 1$ of known positive and negative sera, besides tested sera were added at two fold dilution in blocking buffer (PBST + albumin) to the adsorped PPR antigen (containing $10^{2.2}$ ICID $\mathrm{CIO}_{5} /$ well) and incubated at $37^{\circ} \mathrm{C}$ for 1 hour followed by 3 times wash with PBS, after the last wash $50 \quad 1$ of anti-sheep immunoglobulin conjugate (horseradish peroxidase) at dilution previously established by titration were added and incubated at $37^{\circ} \mathrm{C}$ for 1 hour, then washed 3 times with PBS before $\mathrm{II}_{2} \mathrm{O}_{2}-\mathrm{OPD}$ was added in phosphate citrate buffer and the color was allowed to develop for 10 minutes, the plates were read on Dynatech MR7000 ELISA reader at an absorbance of $492 \mathrm{~nm}$ and the OD values were converted to the anti $\log _{1}$.

\section{Statistical analysis:}

Data were analysed using Student (T) test as explained by Snedocor (1969)

\section{RESULTS}

1-Effect on serum selenium level:

lable (1) shows that the average level of serum selenium before vaccination did not differ among the two groups but after vaccination serum selenium concentration increased significantly $(p<0.001$ $\mathrm{p}<0.05$ ) in selenium treated group (test group) during the whole experimental period, this when compared with the values in prevaccination, while in control group serum selenium level decreased but insignificantly for 6 wccks post vaccination.

\section{2-Effect on antibody titer using both SNT and ELISA technique:}

Tables (2) and (3) show the effect of selenium on antibody titre using SNT (Table 2) and FLISA technique (Table 3). Test group showed a highly significant increase in antibody titer $(p<0.001-0.01)$ from the $1^{\text {st }}$ to $24^{\text {th }}$ week post vaccination. 
Assiut Vel Med. J. Vol. 44 No. 88, Jamuary 2001

Table 1: Serum selenium $\mu \mathrm{g} / \mathrm{dl}$ in sheep vaccinated with PPRvaccine.

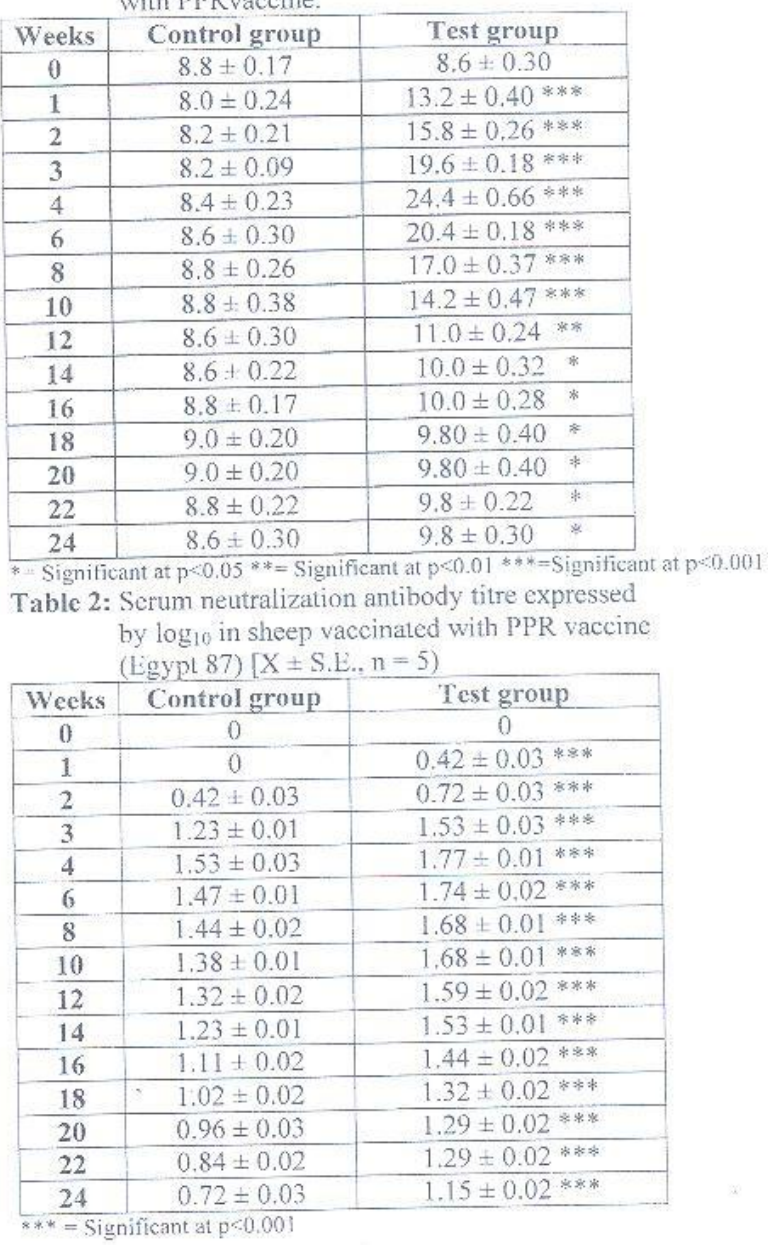


Assiut Vet. Med. J. Vol. 44 No, 88 , Jamuary 2001

Table 3: Serum ELISA antibody titre expressed by $\log 10$ in sheep vaccinated with PPR vaccine (Egypt 87) $[\mathrm{X} \pm$ S.E., $n=5]$

\begin{tabular}{|c|c|c|}
\hline Weeks & Control aroun & Test oroun \\
\hline 0 & 0 & 0 \\
\hline 1 & $0.42 \pm 0.03$ & $0.72 \pm 0.03 * * *$ \\
\hline 2 & $0.84 \pm 0.02$ & $1.11 \pm 0.02 * * *$ \\
\hline 3 & $1.38 \pm 0.01$ & $1.59 \pm 0.02 * * *$ \\
\hline 4 & $1.68 \pm 0.01$ & $1.92=0.01 * * *$ \\
\hline 6 & $1.68 \pm 0.01$ & $1.83 \pm 0.01 * * *$ \\
\hline 8 & $1.65+0.0$ & $1.77 \pm 0.01 * * *$ \\
\hline 10 & $1.53 \pm 0.01$ & $1.77 \pm 0.01 * * *$ \\
\hline 12 & $1.47 \pm 0.01$ & $1.68 \pm 0.01 * * *$ \\
\hline 14 & $1.44 \pm 0.02$ & $1.62 \pm 0.01 * * *$ \\
\hline 16 & $1.38 \pm 0.01$ & $1.53 \pm 0.01 * * *$ \\
\hline 18 & $1.29 \pm 0.02$ & $1.47 \pm 0.01 * * *$ \\
\hline 20 & $1.23 \pm 0.02$ & $1.38+0.01 * * *$ \\
\hline 22 & $1.11 \pm 0.02$ & $1.32 \pm 0.02 * * *$ \\
\hline 24 & $0.92 \pm 0.03$ & $1.26 \pm 0.02 * * *$ \\
\hline
\end{tabular}

\section{DISCUSSION}

The results in Table (1) showed that injection of selenium in a dose of $5 \mathrm{mg} / \mathrm{sheep} \mathrm{(Blood} \mathrm{and} \mathrm{Radostits,} \mathrm{1994)} \mathrm{caused} \mathrm{a} \mathrm{significant}$ increase in serum selenium of vaccinated sheep which allowed an increased synthesis of glutathion peroxidase (GSH-PX) and uptake by other body tissues (Hoffman et al., 1978). This prophylactic injection of selenium have been used successfully for prevention particularly in circumstances where diet cannot be casily supplemented or when animals exposed to stress factors like pregnancy and vaccination, also it may be possible to correct deficiency especially our tested sheep that were at lower adequate level of serum selenium (Cohen, 1991).

The slight decrease in serum selenium in control group as a result of stress exerted by vaccination, increased metabolism and breakdown of body tissues that would lead to the production of greater quantitics of organic peroxides and free radicals (Fridovick, 1978), the level of glutathione peroxidase would increase to combat these deleterious effects; thus sheep might have a higher demand for selenium at vaccination time. 
The results we have obtained confirm the potential inmunostimulant effects of selenium on immune function as indicated by the significant increase in antibody titer in tested group using both SNT and ELISA tests, our results agree with the studies of Spallholz et al. (1973) and Spallholz et al. (1975) in mice, Berenstcin (1978) in rabbits, Sheffy and Schultz (1979) in dogs, Peplowski et al. (1980), Blodgett et al. (1986) and Li and Wang (1995) in pigs, Colango et al. (1984), Bassiouni et al. (1990) and Panda and Roa (1994) in chicks, Baalsrud and Overnes (1986) and Knight and Tyznik (1990) in horses, while Jelinek et al. (1988), Larsen et aㅣ. (1988), Reffett et al. (1989 b) in sheep, but Droke and Loerch (1989), Reffett et al. (1989 a), Swecker et al. (1989), Makimura et al. (1993), Nicholesen et al. (1993) and McEvoy and Pollock (1994) in cattlc. Selenium has been found to affect lymphocyte subpopulation and in vitro interleukin-2 (IL-2) secretion, both of which are involved critically in B-cell activation, selenium may stimulate Bcell to secrete greater quantitics of IgM via selective regulation of lymphocytc subpopulation and lymphokine secretions (Petrie et al., 1989). It may be suggested that the well-known protective role of GSH$\mathrm{PX}$ on membrane integrity might represent at least one of the mechanisms through which selenium enhanced antibody production (Niki ct al., 1991).

The synthetic activity of any individual secretory cell (B-cell) is subject to the chemical and physical integrity of endomembranes and the cell surface (Mepham, 1987), selenium as an essential component of the enzyme glutathione peroxidase (GSH-PX) function as an antioxidant by reducing lipid hydroperoxides once formed to less reactive alcohol (Hoekstra, 1975). The oxidative role becomes very important during the immune response when neutrophils produce large quantities of suneroxides and hydrogen peroxides from molecular oxygen to destroy ingested foreign organism (Ross, 1977) and so selenium modulate the immune response by protecting lymphocytes from the effects of various inhibitory products produced by phagocytosis (Baumgartner, 1979), also Reffett et al. (1988 a) mentioned that selenium stimulate synthesis of Ig $\mathrm{M}$ antibody by increasing the number of IgM producing cells. It could be concluded that selenium may stimulate the immune response of sheep to PPR vaccine. 


\section{REFERENCES}

Anderson, J. and McKay, J.A. (1994): "The detection of antibodies against peste des petits ruminants virus in catlle, sheep and goats and the possible implications to RP control programe" Epidemiol.Infect, 112:225-231.

Baalsrud, R.J. and Overnes, G. (1986): "Influence of vitamin E and selenium on antibody production in horses". Equine Vet.J., $18(6): 472-474$

Bassiouni, A.A; Zaki, M.M. and Maha, M. Haby (1990): "Ellect of vitamin $\mathrm{E}$ and selenium on the immune response of chickens against living Newcastle disease vaccine". Vet.Med.J., Giza, $38(1): 145-155$.

Baumgariner, W.A. (1979): "Antioxidants, cancer and the immune response". Trace metals in health and discase, 295.

Berenstein, J.F. (1978): "Effect of selenium and vitamin $\mathrm{F}$ on antibody formation in rabbits". Selenium and Tellurium abstracts, 14:1 (abst. 23317).

Blodget, D.J.; Schuring, G.G. and Kornegay, E.T. (1986): "Immunomodulation in weanling swine with dictary selenium". Am.J.Vet.Res.. 47(7):1517-1519.

Blood, D.C. and Radostits, O.M. (1994): "Veterinary medicine, A textbook of the diseases of cattle, sheep, pigs, goats and horses". $8^{\text {th }} \mathrm{Ed}$. PP. 1423

Cohen, R.D.U. (1991): "Selenium response in unthriftness in sheep and cattle". Cand.Vet.J. 32;113.

Colango, G.L.: Jensen, L.S. and Long, P.L. (1984): "liffect of selenium and vitamin $\mathrm{E}$ on the development of immunity to coccidiosis in chickens". Poult.Sci., 63:1136-1143.

Droke, E.A. and Loerch, S.C. (1989): "Effects of parentral selenium and vitamin $\mathrm{E}$ on performance, health and humoral immune response of steers new to the leedlot environment". J.Anim.Sci., 67(5):1350-1359.

liridovich, I. (1978): "The biology of oxygen radicals" Sci.(Washington, D.C), 201:875.

Hoekstra, W.G. (1975): "Biochemical function of selenium and its relation to vitamin E". Fed.Proc., 34:2083. 


\section{Assiut Vet. Med. J. Vol. 44 No. 88 , Jamuary 2001}

Hoffman, C.: Rivinus, B. and Swanson, L. (1978): "Effect of intramuscular administration of selenium and vitamin $\mathrm{E}$ in dairy heifers on crythrocyte glutathione peroxidase activity and blood selenium levels". J.Anim.Sci., 47:192.

Ismail, l. (1999): "Effect of addition of selenium and/or zinc to FMD vaccine on the immune response of calves". Ph.D.Vet.Med.Sci.Pharmacol, Zag. Univ., Fgypt.

Jelinek, P.D.: Ellis, T.; Wroth, R.H.; Sutherland, S.S.; Masters, H.G. and Petterson, D.S. (1988): "The effect of selenium supplenentation on immunity and the establishment of an experimental I Iaemoncous contortus infection in weaner merino sheep fed low selenium diet". Aus. Vet.J., 65(7):214. 217.

Knight, D.A. and Tyznik, W.J. (1990): "The effect of dietary selenium on humoral immuno-competence of ponies". J.Anim.Sci. $68(5): 1311-1317$

Kolb. E.; Kaskous, S. and Seehawer. J. (1997): "Nutritional aspects of the importance, utilization, metabolism and the use of vitamin $\mathrm{E}$ and selenium in sheep". Berl.Munch.Tierarztl. Wschr. $110(5): 178-184$.

Larsen, H.J.; Moksnes, $K$. and Overnes, G. (1988): "Influence of selenium on antibody production in sheep". Res.Vet.Sci., 45(1):4-10.

Li, JX and Wang, J.D. (1995): "Studies on selenium for raising the immunc potency of swinc fever vaccinc". Acta.Vet.Lootech.Sinica, 26(5):441-445

Lille, W.; Vogg, M.J, Collis, K.A.; Show, S.R and Gleed, P.T. (1979): "Concentration of selenium by atomic absorption". Res.Vet.Sci. 26:193-197.

Makimura, S.; Kodama, A.; Kishita, M.; Takagi, H. and Adachi, K (1993): "Secondary antibody response to Haemophilus somnus antigen in breeding Japanese black cattle fed selcnium deficient and alpha tocopherol fortified dicts". J.Vet.Med.Sci. $55(5): 871-873$.

McEvoy, J.D. and Pollock, J.M. (1994): "A preliminary study of peripheral lymphocyte function in cows with chronic endometritis". Vet.Rec., 134:237-238.

Mepham. T.B. (1987): "An analysis of lactation as a productive system". Physiology I actation, Philadelphia, Open Union Press, 62-68. 
4ssiut Vet. Med. J. Vol. 44 No. 88. Januarv 2001

Nicholson, J.W.G.; Bush, R.S. and Allen, J.G. (1993): "Nntibody responses of growing beef cattle fed silage diets with and without selenium supplementation". Can.J.Anim.Sci. $73(2): 355-365$.

Niki, E.; Yamamoto, Y. and Komura, E. (1991): "Membrane damage due to lipid oxidation". Am.J.Clin.Nutr., 53:201-205.

Panda, S.K. and Rao, A.T. (1994): "Effect of a vitamin E-selenium combination on chicks infected with infectious bursal discase virus". Vet.Rec., 134:242-243.

Peplowski, M.A.: Mahan, D.C.; Murry, E.A.; Moxon, A.L.: Cantor, A.H. and Ekstram, K.E. (1980): "Effect of dietary and injectable vitamin $E$ and selenium in weanling swine antigcnically challenged with sheep red blood cells". J.Anim.Sci., 51(2): 344-351.

Petrie, H.T.; Klossen, L.W. and Kory, H.D. (1989): "Selenium and the immune response: 1-Modulation of alloreactive human lymphocyte function in vitro". J.Leukocyte Biol., 45:207.

Reed, L.J. and Muench, H. (1938): "Simple method of estimating fifty percent end point". Amer.J.Hyg., 27:793-799.

Reffett, J.K.; Spears, J.W. and Brown, T.T.Jr. (1988a): "Effect of dictary selenium on the primary and secondary immune response in calves challenged with infectious bovine rhinotracheitis virus". J.Nutr., 118(2):229-235.

Reffett, J.K.; Spears, J.W. and Brown, T.T.Jr. (1988b): "liffect of dietary selenium and vitamin $\mathrm{E}$ on the primary and secondary immune response in lambs challenged with parainfluenza virus". J.Anim.Sci., 66(6):1520-1528.

Ross, D. (1977): "Oxidative killing of microorganisms by phagocytic cells". Trends.Biochem.Sci., 2:61

Rossiter, P.B. and Jessette, D.M. (1982): "Microtiter techniques for the assay of rinderpest virus and neutralizing antibody". Res. Vet.Sci, 32:253-256.

Sheffy, B.E. and Schullz, R.D. (1979): "Influence of vitamin E and sclenium on immune response mechanisms". Fed.Proc., $38(7): 2139-2143$.

Snedecor, G.W. (1969): "Stastical Methods". $4^{\text {th }}$ edition. The lowa State Univ.Press, Ames, lowa, USA. Pp.91.

Spallholz, J.E.; Martin, J.L.; Gerlach, M.L. and Heinzerluig, R.II. (1973): "Sclenium: Effect on the primary immune response of mice". Proc.Soc.Exp.Biol,Med., 143:685. 
Spallholz, J.E.; Martin, J.L.: Gerlach, M.L. and Heinzerluig, R.H. (1975): "Injectable selenium : Effects on the primary responsc of mice". Proc.Soc.Exp.Biol.Med., 148(1):37-40.

Swecker, W.S, Eversole, D.E, Thatcher, C.D.; Blodgeti, D.J.; Schuring G.G. and Meldrum, J.B. (1989): "Influence of supplemental selenium on humoral immune response in weaned beef calves". Am.J.Vet.Res., 50(10):1760-1763.

Taylor, W.P. (1984): Preventive Vet.Med., 2:157.

Wichtel. J.J. (1998): "A review of selenium deficiency in grazing ruminants: part I new roles for selenium in ruminant metabolism". N.7.Vet.I., 46(2):47-52. 